\title{
Different Growth and Physiological Responses of Six Subtropical Tree Species to Warming
}

\author{
Yiyong Lit,2, Guoyi Zhou² and Juxiu Liu²* \\ ${ }^{1}$ School of Forestry and Landscape Architecture, Anhui Agricultural University, Hefei, China, ${ }^{2}$ Key Laboratory of Vegetation \\ Restoration and Management of Degraded Ecosystems, South China Botanical Garden, Chinese Academy of Sciences, \\ Guangzhou, China
}

OPEN ACCESS

Edited by:

Boris Rewald,

University of Natural Resources

and Life Sciences, Vienna, Austria

Reviewed by:

Eryuan Liang,

Institute of Tibetan Plateau Research

(CAS), China

Iván Prieto,

Centro de Edafología y Biología Aplicada del Segura (CSIC), Spain

*Correspondence:

Juxiu Liu

ljxiu@scbg.ac.cn

Specialty section:

This article was submitted to Functional Plant Ecology,

a section of the journal

Frontiers in Plant Science

Received: 31 May 2017 Accepted: 16 August 2017 Published: 29 August 2017

Citation:

Li Y, Zhou G and Liu J (2017) Different Growth and Physiological Responses of Six Subtropical Tree

Species to Warming.

Front. Plant Sci. 8:1511.

doi: 10.3389/fpls.2017.01511
Quantifying changes in interspecific plant growth and physiology under climate warming will facilitate explanation of the shifts in community structure in subtropical forest. We evaluated the effects of 3 years climate warming (ca. $\left.1^{\circ} \mathrm{C}, 2012-2015\right)$ on plant growth and physiological parameters of six subtropical tree species by translocating seedlings and soil from a higher to a lower elevation site. We found that an increase in soil/air temperature had divergent effects on six co-occurring species. Warming increased the biomass of Schima superba and Pinus massoniana, whereas it decreased their specific leaf area and intrinsic water use efficiency compared to other species. Warming decreased the foliar non-structural carbohydrates for all species. Our findings demonstrated that a warmer climate would have species-specific effects on the physiology and growth of subtropical trees, which may cause changes in the competitive balance and composition of these forests.

Keywords: climate warming, tree growth, subtropical forest, stomatal traits, non-structural carbohydrates

\section{INTRODUCTION}

Tropical and subtropical forest ecosystems occupy large areas of the global surface and provide important ecosystem services, such as carbon storage, global biogeochemical cycles and the conservation of biodiversity. The impacts of climate warming (Pachauri et al., 2014), however, are gradually representing a prominent disturbance, affecting from individuals to whole ecosystems (Arend et al., 2011). Numerous studies of subtropical and tropical forests have reported that climate warming is changing forest structure and tree mortality (Zhou et al., 2013, 2014). Shifts in plant community composition, plant cover and growth (increases in plant biomass) will affect the vegetation feedbacks to climate change.

Many temperature manipulations have been conducted to quantify growth and physiological responses (Gimeno et al., 2012; Huang et al., 2015). However, because most studies focus on responses of individual tree species, we have little understanding of how warming would affect co-occurring species. Competition with neighboring plants is very common in various ecosystems (Wang et al., 2012; Wang Y. et al., 2016), so that the competitive hierarchies of co-occurring species may re-ranked by divergent morphological and physiological responses under warming (Hikosaka et al., 2005).

Many warming experiments have been conducted in temperate ecosystems where plant growth may be temperature-limited (Way and Oren, 2010). Increased biomass production of tree seedlings under elevated temperature were observed in these warming experiments 
(Ghannoum et al., 2010; Way and Oren, 2010; Sendall et al., 2014), although responses were often small or transient and varied across species and study site (Lin et al., 2010). However, the responses of tropical and subtropical tree species to climate warming remain unexplored. Several studies suggested that tropical tree species which have narrower temperature tolerance may be more susceptible than temperate tree species under future warming scenarios (Sala et al., 2000; Cunningham and Read, 2002). In addition, biomass allocation patterns may be altered when plants are exposed to warming (Kasurinen et al., 2016; Wang P. et al., 2016). However, there are quite few experiments which have been carried out in tropical and subtropical areas, and responses of plant growth in tropical and subtropical forest ecosystems remain poorly resolved.

Plant growth may be affected directly by response of biochemical (i.e., photosynthesis) (Smith and Dukes, 2013) and physiological processes (i.e., stomatal conductance) (Zheng et al., 2013), or indirectly by changes in nutrient and water availability (Jónsdóttir et al., 2005). In connection with plant growth and carbon assimilation, stomatal traits including the length and density of stomata, which can determine the maximum stomatal conductance to $\mathrm{CO}_{2}$ and $\mathrm{H}_{2} \mathrm{O}$ (Franks and Beerling, 2009), could change to optimize their gas exchange (Zhang et al., 2010). Changes in stomatal apertures and density are often associated with changes in water-use efficiency (Franks et al., 2015) which can affect plant growth and water stress (Han et al., 2013). It is widely recognized that plants must achieve a balance between carbon assimilation, carbon storage and growth, all of which are directly or indirectly affected by climate warming (Smith and Stitt, 2007). The concentration of non-structural carbohydrates (NSC) within plant tissues, which depends on the balance between carbon supply (i.e., photosynthesis) and carbon demand (i.e., growth) (Michelot et al., 2012), were considered to decrease under short-term warming (Huang et al., 2015). Therefore, it is necessary to study the interaction among carbon assimilation rate, plant biomass and NSC under warming.

The coniferous and broad leaved mixed forest represents one of the most widespread secondary vegetations and developed well in southern subtropical China. Shifts in the structure and distribution of these forests under climate warming are likely to have important consequences. Here, we conducted a downward translocation (translocate soil and trees from 300 to $30 \mathrm{~m}$ a.s.l) experiment to examine the effects of elevated temperature on tree growth and physiological performance of six subtropical tree species in a mixed forest. In light of previous studies ( $\mathrm{Li}$ et al., 2016a,b), we tested the following hypotheses: (1) the six species would show divergent responses of tree growth and biomass allocation pattern, and (2) warming cause adjustments in plant morphology and physiology to support growth.

\section{MATERIALS AND METHODS}

\section{Study Site}

We conducted this research at Dinghushan Biosphere Reserve, an UNESCO / MAB site located in the central Guangdong Province in southern China $\left(112^{\circ} 10^{\prime} \mathrm{E}, 23^{\circ} 10^{\prime} \mathrm{N}\right)$. The local climate is typical south subtropical monsoon, with mean annual precipitation of $1956 \mathrm{~mm}$ and mean annual temperature of $21^{\circ} \mathrm{C}$. The bedrock is sandstone and shale. Soils are classified as ultisols with a $\mathrm{pH} 4.0-4.9$ in the top $5 \mathrm{~cm}$.

\section{Translocation Experiment}

We selected two field translocation sites, one control site and one warm site (at $300 \mathrm{~m}$ and $30 \mathrm{~m}$ a.s.l, respectively). At each site, we selected three $3 \times 3 \mathrm{~m}$ plots in an open area and then shielded below-ground ( $0.8 \mathrm{~m}$ deep) with concrete brick wall bonding with ceramic tile, leaving one hole connected with PVC tube at the bottom and the top of the wall to collect underground water and surface runoff, respectively. In April 2012, soil and 1-yearold seedlings were collected from a coniferous and broadleaved mixed forest that is near the control site. Three different layers of soils (0-20, 20-40, and 40-70 cm) were homogenized separately. Seedlings were stored in shade containers with soil from the collection sites. In May 2012, three different layers of soils were transferred into the plots correspondingly. The seedlings were transplanted into the plots in a randomized block design $(n=6$ replicates per species).

The six species included in this study were specifically selected due to their common occurrence and distribution range (existence in almost all regions along the altitudinal gradient) from the mixed forest. They included Schima superba Gardn. et Champ, Syzygium rehderianum Merr. et Perry, Machilus breviflora (Benth.) Hemsl, Pinus massoniana Lamb., Castanopsis hystrix Hook. f. et Thomson ex A. DC, Ardisia punctata Lindl. All species were evergreen, ensuring that their leaves are exposed to the full seasonal changes of temperature. Coniferous and broadleaved species ( $P$. massoniana vs other species) were chosen.

Each plot was installed with a meteorological station to record air temperature (HMP155A, Vaisala, Finland). We continuously monitored soil temperatures and soil moisture (0-10 cm depth) using automated sensors (CT 109, CS616 and CR1000 Data Loggers, Campbell, United States). More detailed information about the collection and establishment of the experiment has been reported previously ( $\mathrm{Li}$ et al., 2016a,b).

\section{Growth Measurements and Sample Collection}

Tree height and basal diameter were measured at the time of planting in May 2012 and then assessed in June annually. Plant height was measured as the distance between the soil surface and the tip of the apical bud. The basal diameter was assessed at the soil surface. One tree per species in each chamber was destructively harvested in June 2014 and June 2015. The soil on the roots was carefully removed, and any root material in the soil was also collected. The fresh weights of all leaves, stems and branches, and roots of the harvested trees were measured. Then samples of leaves, stem and branches, and roots were collected to calculate dry/fresh ratio (oven-dried at $65^{\circ} \mathrm{C}$ until constant weight / fresh weight). The biomass of each harvested tree was calculated with fresh weights of all organs and dry/fresh ratio. 


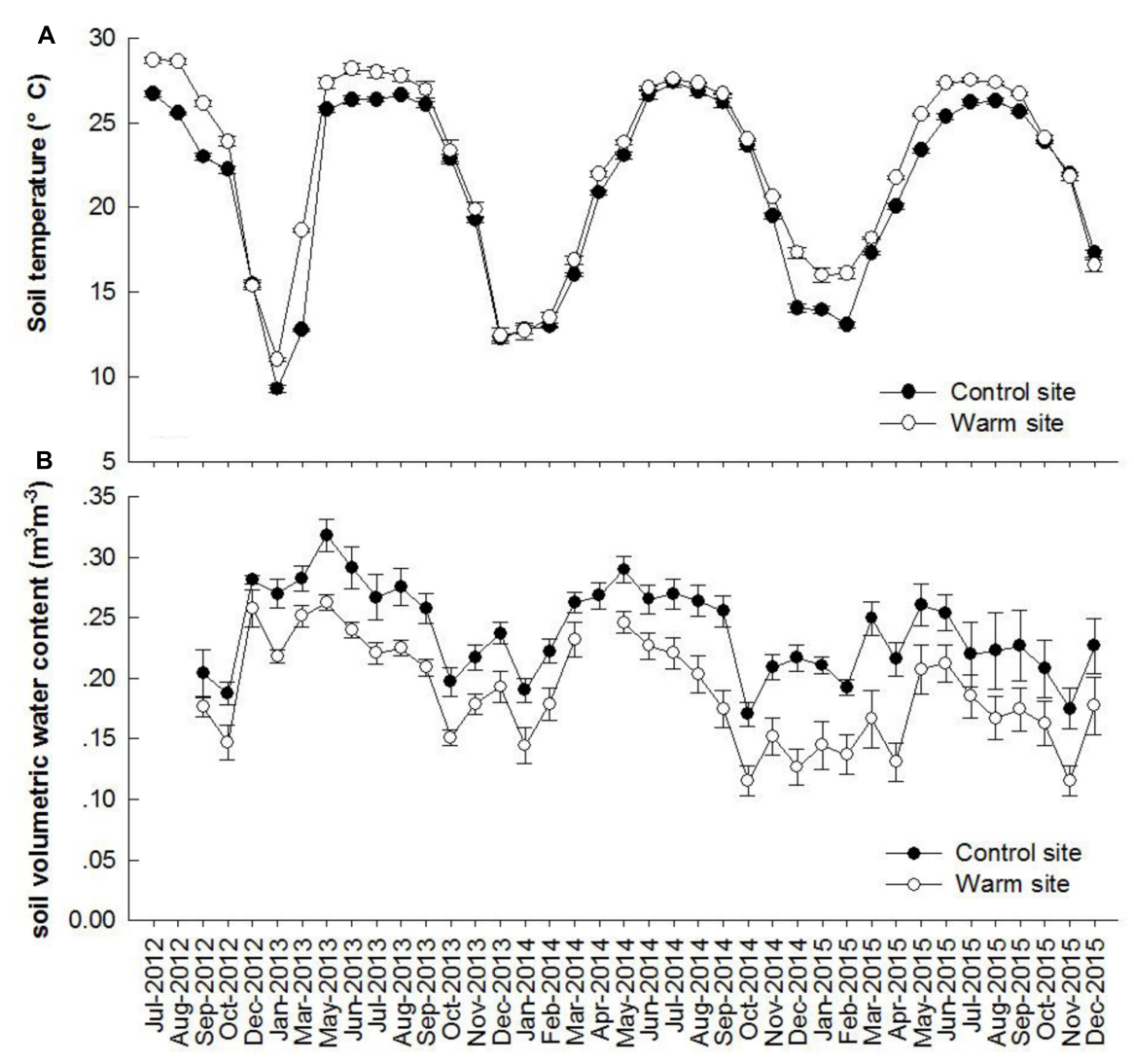

FIGURE 1 | Dynamics of soil temperature (A), volumetric water content (B) at $10 \mathrm{~cm}$ depth in the control and warm sites from July 2012 to December 2015. Error bars are standard error.

Strong correlations among dry biomass for each component part, basal area and height existed irrespective of size in trees harvested, which were stated in the equation:

$$
B=a \times\left(D^{2} H\right)+b
$$

Where $B$ is dry biomass of each tree components including root, stem and leaf $\left(\mathrm{g} \mathrm{m}^{-2}\right), a, b$ represent the regression coefficients, $D$ is plant basal diameter $(\mathrm{cm}), H$ is tree height $(\mathrm{cm})$, and $a, b$ are regression coefficients (See Supplementary Table S1). The biomass of other un-harvested tree was calculated separately using their height and basal diameter and the allometric relationship described by the equation above.

In June 2015, total plant leaf area was determined by a portable leaf area meter (LI-3100A, Li-Cor, United States). For each harvested seedling, specific leaf area [Specific leaf area (SLA); leaf area/leaf biomass. $\mathrm{cm}^{2} \mathrm{~g}^{-1}$ ] and leaf area ratio [leaf area ratio (LAR); total leaf area/total plant biomass, $\mathrm{cm}^{2} \mathrm{~g}^{-1}$ ] were calculated. As $P$. massoniana is a needle-leaved species which could not be measured for leaf area, we only studied the other five species for SLA and LAR in our experiment. The whole plant biomass, the fraction of biomass allocated to roots [root mass ratio (RMR); roots mass fraction], leaves [leaf mass ratio (LMR); leaves mass fraction] and stems [shoot mass ratio (SMR); stems mass fraction] and the roots to shoots ratio (R/S; roots biomass/shoots biomass) were also calculated.

\section{Leaf C Isotope Discrimination and Non-structural Carbohydrate (Soluble Sugar and Starch)}

Leaf samples from the destructive harvests in June 2015 were oven dried at $70^{\circ} \mathrm{C}$ and ground to powder to analyze leaf $\mathrm{C}$ isotope discrimination $\left(\delta^{13} C\right)$ and soluble carbohydrates. The leaf $\mathrm{C}$ isotope discrimination $\left(\delta^{13} C\right)$ has been increasingly accepted as an index to infer intrinsic water use efficiency (Dawson et al., 2002). The $C$ stable isotope composition was obtained by mass spectrometry (Finnigan Mat, Delta S, Bremen, Germany) in the public laboratory of Southern China Botanical Garden, Chinese Academy of Sciences, with Pee Dee Belemnite as standard. The $\delta^{13} C$ (in parts per thousand, \%o) was as (Farquhar et al., 1989):

$$
\delta^{13} C=\left(R_{\text {sample }} / R_{\text {standard }}-1\right) \times 1000
$$

where $R_{\text {sample }}$ and $R_{\text {standard }}$ are the ${ }^{13} C:{ }^{12} C$ ratios of the leaf sample and the ${ }^{13} \mathrm{C} /{ }^{12} \mathrm{C}$ ratio of the international Pee Dee Beleminite (PDB) standard. 
TABLE 1 | Effects of warming, species and their interactions on growth and physiological parameters.

\begin{tabular}{|c|c|c|c|c|c|c|}
\hline Variables & Warming & Df & Species & Df & Warming*Species & Df \\
\hline Stem diameter & $25.0^{* * *}$ & 1 & $101.6^{* * *}$ & 5 & $17.4^{* * *}$ & 5 \\
\hline Tree height & $49.6^{* * *}$ & 1 & $101.2^{* * *}$ & 5 & $7.9 * * *$ & 5 \\
\hline Stomatal length & $16.8^{* *}$ & 1 & $173.8^{* * *}$ & 4 & 0.6 & 4 \\
\hline Stomatal density & $6.4^{*}$ & 1 & $28.8^{* * *}$ & 4 & 0.9 & 4 \\
\hline Biomass & $6.4^{*}$ & 1 & $15.1^{* * *}$ & 5 & $3.0^{*}$ & 5 \\
\hline Root mass ratio & 0.1 & 1 & $398.9^{* * *}$ & 5 & $5.4^{* *}$ & 5 \\
\hline Stem mass ratio & 1.4 & 1 & $545.1^{* * *}$ & 5 & 0.5 & 5 \\
\hline Leaf mass ratio & 0.2 & 1 & $58.4^{* * *}$ & 5 & $4.5^{* *}$ & 5 \\
\hline Root / Shoot & 0.5 & 1 & $668.9^{* * *}$ & 5 & $2.7^{*}$ & 5 \\
\hline Specific leaf area & $83.9 * * *$ & 1 & $44.5^{* * *}$ & 4 & $4.7^{* *}$ & 4 \\
\hline Leaf area ratio & $26.1^{* * *}$ & 1 & $15.7^{* * *}$ & 4 & 1.4 & 4 \\
\hline Leaf $\delta^{13} C$ & $4.7^{*}$ & 1 & $69.2^{* * *}$ & 5 & $8.0^{* * *}$ & 5 \\
\hline Soluble sugar & $23.9^{* * *}$ & 1 & $15.7^{* * *}$ & 5 & 0.9 & 5 \\
\hline Starch & $21.8^{* * *}$ & 1 & $93.6^{* * *}$ & 5 & $8.1^{* * *}$ & 5 \\
\hline
\end{tabular}

Numbers and $d f$ s are F-values and their degrees of freedom, respectively. Asterisks indicate the level of significance (no asterisk $=$ not significant, $* p<0.05,{ }^{* *} p<0.01$, $* * * p<0.001)$.
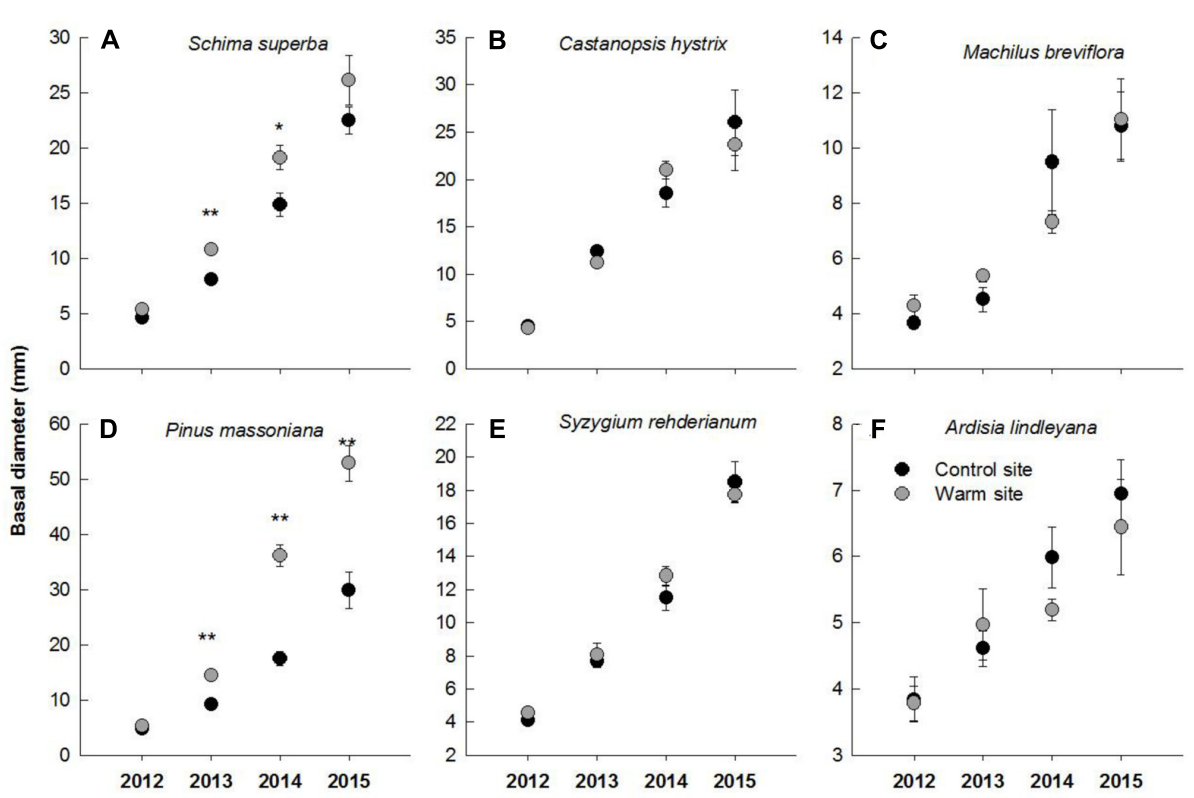

FIGURE 2 | Basal diameter of six tree species in the control and warm sites from June 2012 to June 2015. Schima superba (A), Castanopsis hystrix (B), Machilus breviflora (C), Pinus massoniana (D), Syzygium rehderianum (E), and Ardisia lindleyana (F). Error bars are standard error. ${ }^{*} p<0.05 ;{ }^{* *} p<0.01$.

Methods of soluble sugar and starch assay were described in Mitchell et al. (2013) with some modifications. Soluble carbohydrates were extracted using an ethanol technique and determined using the anthrone colorimetric assay (Ebell, 1969). The concentrations were calculated by comparing with glucose standards, expressed as $\mathrm{mg}$ glucose $\mathrm{g}^{-1} \mathrm{DW}$.

\section{Stomatal Length and Stomatal Density}

In June 2014 and 2015, three leaves per tree were collected from all tree species except for $P$. massoniana in each chamber. Leaf epidermises on the adaxial side were taken centrally in the leaf midway. The epidermises were mounted on a microscope slide and observed using a light microscope (DM2500, Leica, Germany). For each epidermal peel, 20 stomata were sampled to measure length and 3 fields $(300 \mu \mathrm{m} \times 300 \mu \mathrm{m})$ were sampled for density. As stomatal traits of $P$. massoniana could not be measured using this method, we only studied other five species for stomatal traits.

\section{Statistical Analysis}

Basal diameter, tree height as well as stomatal traits were analyzed using a repeated-measures analysis of variance (RMANOVA) with warming (referred to downward translocation), species and their interaction as independent factors. Two-way 

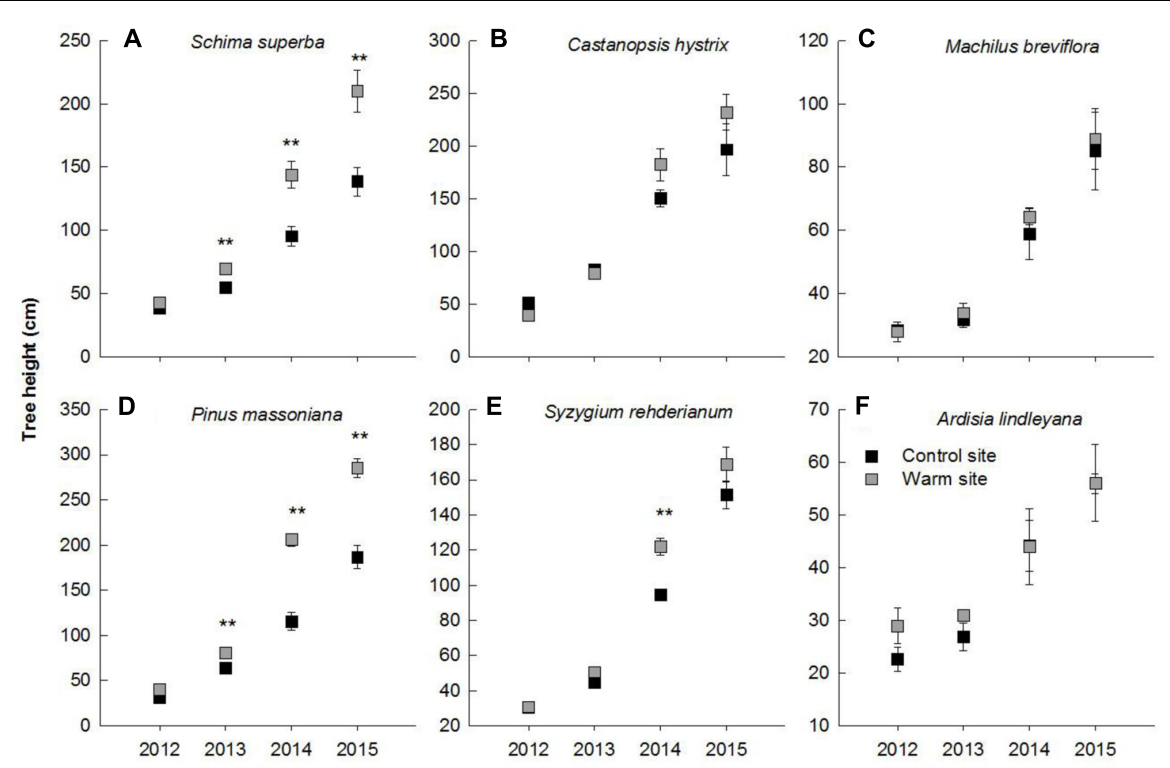

FIGURE 3 | Tree height of six tree species in the control and warm sites from June 2012 to June 2015. Schima superba (A), Castanopsis hystrix (B), Machilus breviflora (C), Pinus massoniana (D), Syzygium rehderianum (E), and Ardisia lindleyana (F). Error bars are standard error. ${ }^{*} p<0.05 ;{ }^{* *} p<0.01$.
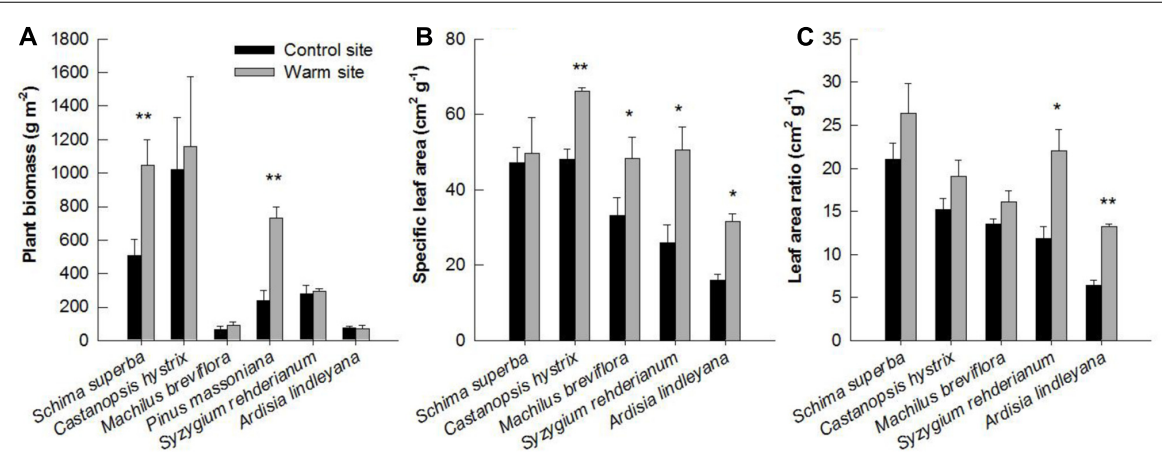

FIGURE 4 | Plant biomass (A), specific leaf area (B), and leaf area ratio (C) of six species in the control and warm sites in June 2015. Error bars are standard error. ${ }^{*} p<0.05 ;{ }^{* *} p<0.01$.

ANOVA was used to assess the effects of warming, species and their interaction on other growth and physiological traits. Data analyses were carried out using SPSS 17.0 (SPSS Inc., Chicago, IL, United States). T-test was also used to analyze the significant differences in these parameters as well as soil moisture and temperature between warm and control site. All analyses were conducted using SPSS 17.0 (SPSS Inc., Chicago, IL, United States). Variables normality and residual homocedasticity were checked.

\section{RESULTS}

\section{Soil Temperature and Soil Volumetric Water Content}

Soil temperature and soil moisture exhibited clear seasonal patterns (Figure 1). From July 2012 to December 2015, monthly soil temperature was on average $1.27^{\circ} \mathrm{C}$ higher under warming $(p<0.05$, Figure 1A). From September 2012 to December 2015 , mean soil volumetric water content were 0.19 and 0.23 $\mathrm{m}^{3} \mathrm{~m}^{-3}$ in the warm and control sites, respectively $(p<0.05$, Figure 1B).

\section{Tree Growth and Biomass Allocation}

In general, warming, species and their interactions had significant effects on basal diameter, height and biomass over the entire experimental period (Table 1). Warming significantly increased basal diameter of S. superba (+33 and $+28 \%$ in 2013 and 2014, respectively) and $P$. massoniana $(+57,+106$, and $+77 \%$ in 2013, 2014, and 2015, respectively) ( $p<0.05$, Figures 2A,D) (Figure 2); however, it had no significant effect on other tree species. Tree height of S. superba $(+28,+51$, and $+51 \%$ in 2013 , 2014, and 2015, respectively), P. massoniana $(+27,+78$, and $+53 \%$ in 2013,2014 , and 2015 , respectively) and S. rehderianum 

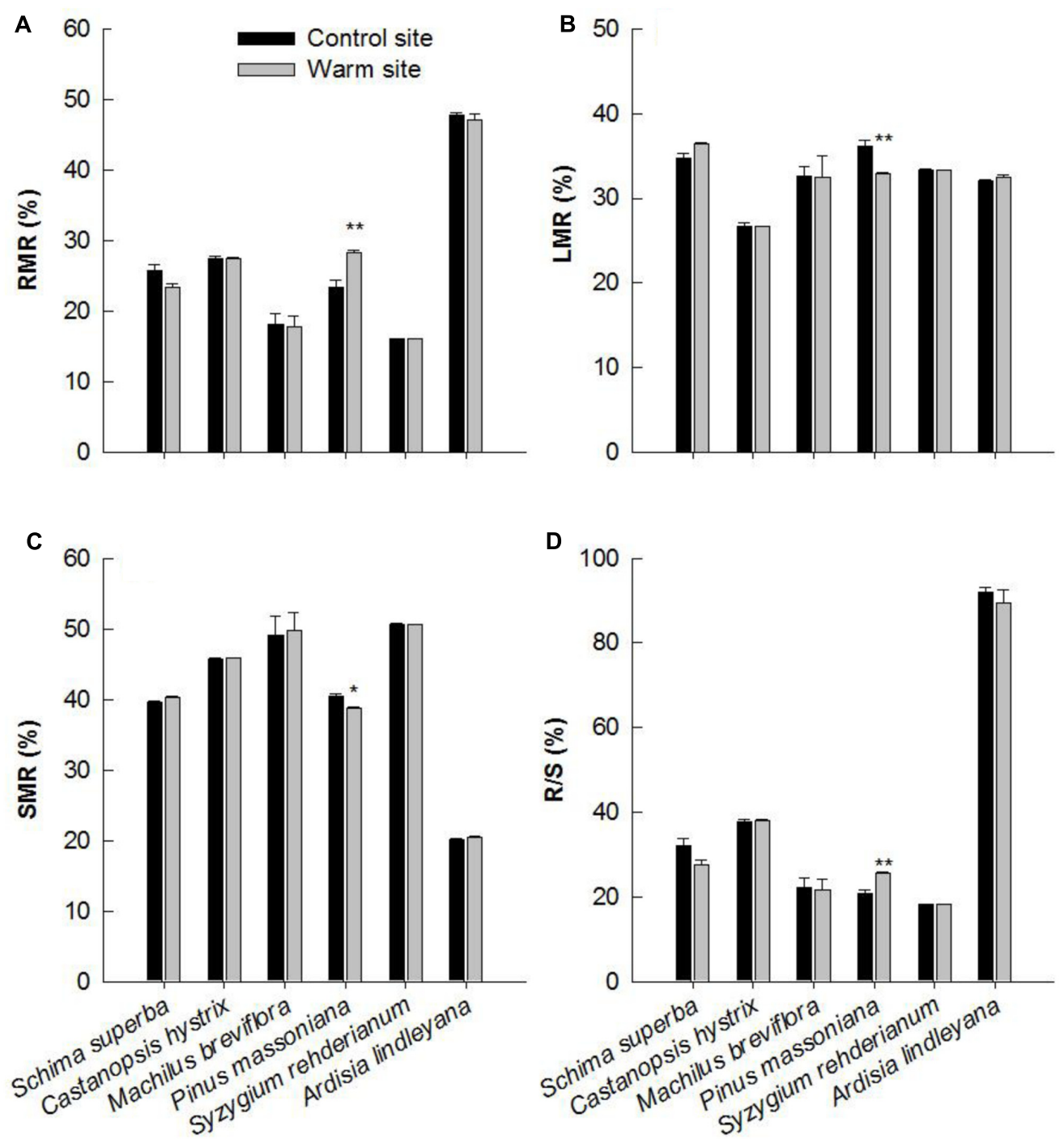

FIGURE 5 | Plant biomass allocation of six species at warm and control site in June 2015. (A) RMR: root mass ratio, (B) LMR: leaf mass ratio, (C) SMR: stem mass ratio, (D) R/S: root/shoot mass ratio. Error bars are standard error. ${ }^{*} p<0.05 ;{ }^{* *} p<0.01$.

$(+29 \%$ in 2014) were significantly higher under warming ( $p<0.05$, Figures 3A,D,F) (Figure 3). In 2015, warming significantly increased whole plant biomass of S. superba and P. massoniana by $107 \%$ and $206 \%$, respectively $(p<0.05)$, but did not significantly affect other tree species $(p>0.05)$ (Figure 4A).

Except for $P$. massoniana, warming had no significant effect on biomass allocation patterns in June 2015 (Table 1). P. massoniana had greater RMR and root/shoot $(\mathrm{R} / \mathrm{S})$, lower LMR and SMR under warming $(p<0.05$, Figure 5).

Specific leaf area and LAR were significantly affected by downward translocation in June 2015 (Table 1). Except for S. superb, SLA of other species was significantly higher in the warm sites compared to those in the control site for all species $(p<0.05)$ (Figure 4B). LAR of $S$. rehderianum and A. lindleyana in the warm site were significantly greater than that in the control site $(p<0.05$, Figure 4C).

\section{Leaf $\delta^{13} C$}

Warming, species and their interactions significantly affected leaf $\delta^{13} C$ in June 2015 (Table 1). Leaf $\delta^{13} C$ of $S$. rehderianum and $A$. lindleyana was significantly lower under warming, but leaf $\delta^{13} C$ of $C$. hystrix was significantly higher under warming $(p<0.05$, Figure 6).

\section{Non-structural Carbohydrates}

Leaf soluble sugar and starch varied significantly between species and were all affected significantly by warming in June 2015 (Figures 7A,B and Table 1). The soluble sugar of S. superba, $S$. rehderianum, $C$. hystrix and $M$. breviflora was $22,23,30$, and $29 \%$ lower under warming, respectively ( $p<0.05$, Figure 7A). 


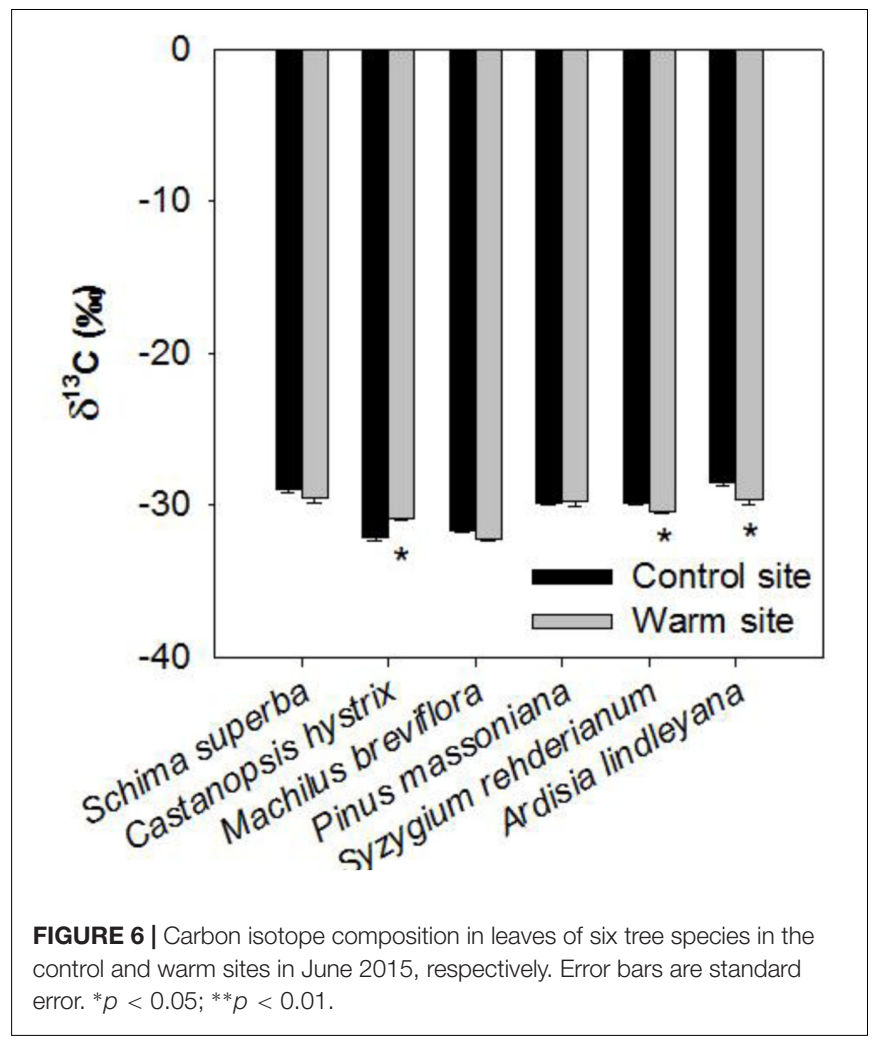

The starch of S. superba, C. hystrix, and M. breviflora was 30,62 , and $35 \%$ lower under warming, respectively $(p<0.05$, Figure 7B).

\section{Stomatal Length and Stomatal Density}

Stomatal length and stomatal density varied significantly between tree species and were affected significantly by warming
(Tables 1, 2). Warming significantly decreased stomatal density of S. superba and C. hystrix by 17 and $30 \%$ in 2015 $(p<0.05)$.

\section{DISCUSSION}

Consistent with our first hypothesis, we observed significant interspecific variation in growth between six species in response to warming, with $S$. superba and $P$. massoniana exhibiting greater increments in growth. P. massoniana, which is a native gymnosperm species, has greater competitive ability and growth rates than other coexisting species at the early successive stage (Tang et al., 2011). It has been suggested that warming can stimulate growth of herbaceous monocots, woody gymnosperms and eucalyptus species (McCulloh et al., 2016; Lemoine et al., 2017; Liu et al., 2017; Sharwood et al., 2017). For example, Hou et al. (2011) found that short-term warming stimulated tree growth in height but had no effect on ring width in Abies faxoniana seedlings. In Juniperus thurifera seedlings, increasing warming temperatures significantly enhanced radial growth rate (Gimeno et al., 2012). Similarly, we observed significant enhancement in height, basal diameter and biomass of $S$. superba and $P$. massoniana in response to warming (Figure 2). The enhancement in biomass production of these two species was substantial, being close to 107 and 206\% in 2014, respectively. This result was in contradiction to results in previous studies that tropical and subtropical tree species may be near a high temperature threshold (Cunningham and Read, 2002; Clark et al., 2010; Way and Oren, 2010; Bowman et al., 2014), which may result from different plant adaptabilities and local soil water conditions under a warmer environment (Crous et al., 2013). Furthermore, our results showed that the biomass allocation pattern of $P$. massoniana was significantly different between the warm and control sites (Figure 5). Roots of P. massoniana

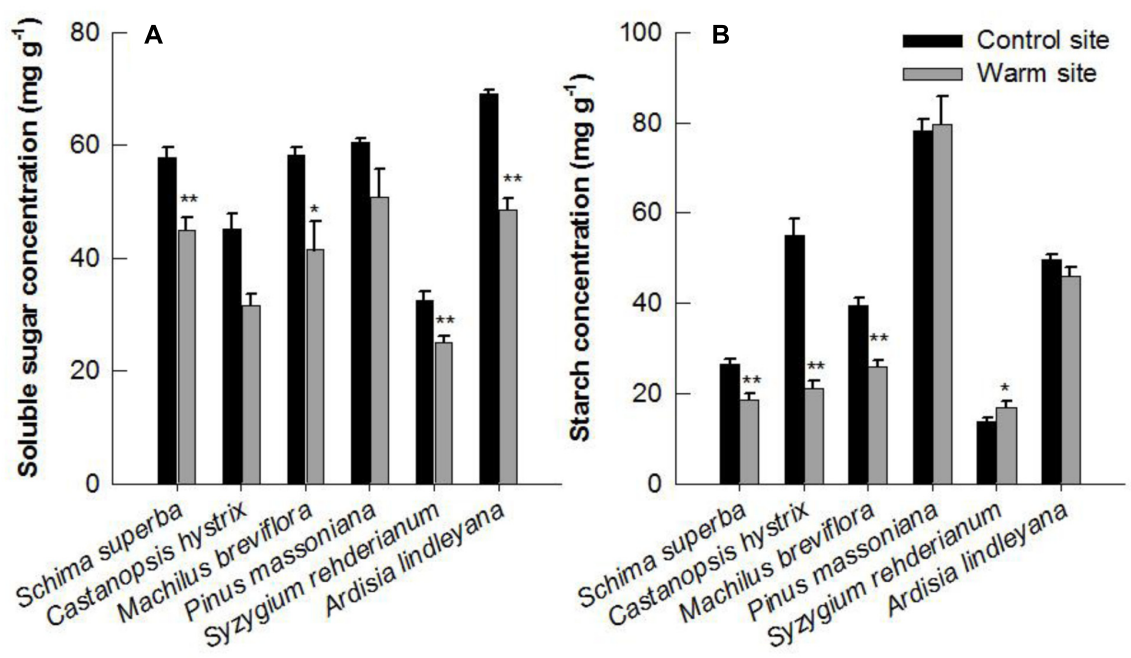

FIGURE 7 | Soluble sugar (A) and starch concentration (B) in leaves of six species in the control and warm sites in June 2015. Error bars are standard error. ${ }^{*} p<0.05 ;{ }^{* *} p<0.01$. 
TABLE 2 | Stomatal length and stomatal density in five tree species in warm and control site in June 2014 and 2015.

\begin{tabular}{|c|c|c|c|c|}
\hline Year & Species & Site & Stomatal length $(\mu \mathrm{m})$ & Stomatal density (stomata/mm $\mathrm{mm}^{-2}$ ) \\
\hline \multirow[t]{2}{*}{2014} & Schima superba & Control & $12.11 \pm 1.67$ & $438.8 \pm 119.2$ \\
\hline & & Warm & $11.90 \pm 1.28$ & $442.5 \pm 82.7$ \\
\hline \multirow[t]{2}{*}{2015} & & Control & $13.56 \pm 0.91$ & $509.8 \pm 67.9^{*}$ \\
\hline & & Warm & $12.37 \pm 0.70$ & $424.6 \pm 15.4$ \\
\hline \multirow[t]{2}{*}{2014} & Syzygium rehderianum & Control & $12.57 \pm 3.24$ & $348.1 \pm 44.1$ \\
\hline & & Warm & $10.74 \pm 1.44$ & $345.6 \pm 63.6$ \\
\hline \multirow[t]{2}{*}{2015} & & Control & $10.53 \pm 0.09$ & $412.3 \pm 50.2$ \\
\hline & & Warm & $10.59 \pm 0.42$ & $440.4 \pm 49.7$ \\
\hline \multirow[t]{2}{*}{2014} & Castanopsis hystrix & Control & $11.03 \pm 1.07$ & $437.0 \pm 45.0$ \\
\hline & & Warm & $10.06 \pm 1.31$ & $465.4 \pm 54.8$ \\
\hline \multirow[t]{2}{*}{2015} & & Control & $10.48 \pm 0.48$ & $481.4 \pm 75.1^{*}$ \\
\hline & & Warm & $10.59 \pm 0.76$ & $337.9 \pm 32.2$ \\
\hline \multirow[t]{2}{*}{2014} & Machilus breviflora & Control & $11.02 \pm 0.89$ & $386.4 \pm 80.6$ \\
\hline & & Warm & $10.56 \pm 0.76$ & $304.9 \pm 118.9$ \\
\hline \multirow[t]{2}{*}{2015} & & Control & $9.93 \pm 0.45$ & $380.2 \pm 5.66$ \\
\hline & & Warm & $8.42 \pm 0.89$ & $409.2 \pm 33.4$ \\
\hline \multirow[t]{2}{*}{2014} & Ardisia lindleyana & Control & $17.99 \pm 1.00$ & $244.0 \pm 47.2^{* *}$ \\
\hline & & Warm & $16.78 \pm 1.97$ & $200.0 \pm 49.3$ \\
\hline \multirow[t]{2}{*}{2015} & & Control & $16.52 \pm 1.24$ & $311.0 \pm 54.4$ \\
\hline & & Warm & $15.43 \pm 1.50$ & $242.0 \pm 58.1$ \\
\hline
\end{tabular}

$* p<0.05 ; * * p<0.01$

received greater biomass under warming, whereas there was less biomass allocation to stems and needles. It has been discovered that warming increases the allocation of dry mass to stems, leaves at the expense of roots (Wang et al., 2012; Dawes et al., 2015). In the present study, the enhanced growth performance in response to warming indicated that temperature dominate plant growth, regardless of limited water content. Higher R/S of P. massoniana under warming also indicated that in a changing environment the species has certain plasticity in biomass allocation.

In this study, significant increases in SLA of C. hystrix, M. breviflora, S. rehderianum, and A. lindleyana were observed under warming (Figure 4B), which means that there is a larger amount of leaf area displayed per unit mass in these four species (Poorter et al., 2009). Higher SLA is associated with efficient light capture and could have led to larger assimilation gains (Wang et al., 2012). Significant differences in LAR of $S$. rehderianum and $A$. lindleyana found between warm and control sites indicated that the same amount of whole plant biomass supported a larger leaf area in the warm site (Figure 4C). Consistent with our previous studies, from 2012 to 2014, the mean average photosynthetic rates under saturating light for S. superba, M. breviflora, P. massoniana, and A. lindleyana in the warm site were $7,19,20$, and 29\% higher under warming (Li et al., 2016a). The warming-induced changes in plant biomass production could have directly resulted from enhanced plant photosynthesis due to higher temperature.

In our study, the leaf starch and soluble sugar content decreased significantly under warming (Figure 7). Similar results have been previously reported in other tree species (Deslauriers et al., 2014; Jamieson et al., 2015). The decrease in concentration of carbohydrates may due to the higher foliar respiration rate under warming, which will result in increased consumption of assimilates, such as starch and sugars (Dietze et al., 2014). Soluble sugar and starch accumulation in leaves can have direct effects on photosynthesis through physiological mechanisms (Pritchard et al., 1997), biochemical feedbacks (Rasse and Tocquin, 2006) and gene-expression control (Moore et al., 1999). Furthermore, more carbon may be available to allocate to growth under warming. A previous study suggested that leaf respiration acclimated more strongly than photosynthesis under warming, increasing carbon assimilation but moderating carbon losses (Way and Oren, 2010). Therefore, our results suggest that the response of photosynthesis and carbohydrates allocation contributed directly to the divergent response of tree growth under warming.

Furthermore, the present results showed that warming decreased stomatal density in S. superba, C. hystrix, and A. lindleyana, and had significant effect on stomatal length (Tables 1, 2). Many previous studies have also found warming affected stomatal density and length due to the changes in epidermal cell density (Zheng et al., 2013; Carins Murphy et al., 2016). Lower stomatal density might be induced by elevated temperature, limited water supply and slightly higher vapor pressure deficit (VPD) in the warm site. Our previous studies have reported that the VPD in the warm site was significantly lower than in the control site ( $\mathrm{Li}$ et al., 2016a). These results suggested that the leaf maximum stomatal conductance and transpiration rate may be constrained by the negative relationship between stomata density and elevated temperature (Franks et al., 2009). It has been previously reported that manipulation of stomatal density could change both instantaneous and long-term 
water use efficiency (WUE) without altering the photosynthetic capacity (Franks et al., 2015). In our study, significant decrease of leaf $\delta^{13} C$ in $S$. rehderianum and $A$. lindleyana were observed under warming (Figure 6), which indicates that warmingdecreased WUE in these two species (Dawson et al., 2002). However, C. hystrix under warming showed significantly higher leaf $\delta^{13} C$-value. In our previous study, we found that warming stimulated photosynthesis in $S$. rehderianum and A. lindleyana and decreased it in C. hystrix (Li et al., 2016a). Higher WUE in C. hystrix under warming has probably been caused by a lowed stomatal conductance and hence a reduced water loss (Li et al., 2016a), together with a reduction in photosynthesis. The decreases of WUE in S. rehderianum and A. lindleyana under warming may have caused by greater water losses due to increased VPD (León-Sánchez et al., 2016; Li et al., 2016a).

\section{CONCLUSION}

We found an increase in total biomass production, a shift in the allocation pattern and changes in the physiological in seedlings grown between the warm and the control site for 3 years. The pattern of response was not uniform between species: our data suggest that $S$. superba and $P$. massoniana growth has increased to a greater extent than other species. Therefore, we can conclude that, climate warming may have pronounced effects on trees' morphology and physiology to support growth under

\section{REFERENCES}

Arend, M., Kuster, T., Günthardt-Goerg, M. S., and Dobbertin, M. (2011). Provenance-specific growth responses to drought and air warming in three European oak species (Quercus robur, Q. petraea and Q. pubescens). Tree Physiol. 31, 287-297. doi: 10.1093/treephys/ tpr004

Bowman, D. M., Williamson, G. J., Keenan, R., and Prior, L. D. (2014). A warmer world will reduce tree growth in evergreen broadleaf forests: evidence from Australian temperate and subtropical eucalypt forests. Glob. Ecol. Biogeogr. 23, 925-934. doi: 10.1111/geb.12171

Carins Murphy, M. R., Jordan, G. J., and Brodribb, T. J. (2016). Cell expansion not cell differentiation predominantly co-ordinates veins and stomata within and among herbs and woody angiosperms grown under sun and shade. Ann. Bot. 118, 1127-1138. doi: 10.1093/aob/ mcw167

Clark, D. B., Clark, D. A., and Oberbauer, S. F. (2010). Annual wood production in a tropical rain forest in NE Costa Rica linked to climatic variation but not to increasing CO2. Glob. Change Biol. 16, 747-759. doi: 10.1111/j.1365-2486.2009. 02004.x

Crous, K. Y., Quentin, A. G., Lin, Y.-S., Medlyn, B. E., Williams, D. G., Barton, C. V. M., et al. (2013). Photosynthesis of temperate Eucalyptus globulus trees outside their native range has limited adjustment to elevated CO2 and climate warming. Glob. Change Biol. 19, 3790-3807. doi: 10.1111/gcb. 12314

Cunningham, S., and Read, J. (2002). Comparison of temperate and tropical rainforest tree species: photosynthetic responses to growth temperature. Oecologia 133, 112-119. doi: 10.1007/s00442-0021034-1

Dawes, M. A., Philipson, C. D., Fonti, P., Bebi, P., Hättenschwiler, S., Hagedorn, F., et al. (2015). Soil warming and CO2 enrichment induce biomass shifts in alpine tree line vegetation. Glob. Change Biol. 21, 2005-2021. doi: 10.1111/gcb. 12819 limited soil water condition, inter-specific competition in the subtropical mixed forest. Warmer environment may increase the competitive advantage of $S$. superba and P. massoniana. Continued warming may thus lead to changes in the competitive balance and, ultimately, the composition of these mixed forests.

\section{AUTHOR CONTRIBUTIONS}

JL and GZ conceived and designed the experiments. YL performed the experiments and wrote the main manuscript. All authors contributed to writing and editing the manuscript.

\section{FUNDING}

This study was financially supported by National Natural Science Foundation of China (Grant No. 31570482, 31370530, and 31670487) and Fund of Anhui Agricultural University (2016ZR018 and yj2017-15).

\section{SUPPLEMENTARY MATERIAL}

The Supplementary Material for this article can be found online at: http://journal.frontiersin.org/article/10.3389/fpls.2017.01511/ full\#supplementary-material

Dawson, T. E., Mambelli, S., Plamboeck, A. H., Templer, P. H., and Tu, K. P. (2002). Stable isotopes in plant ecology. Annu. Rev. Ecol. Evol. Syst. 33, 507-559. doi: 10.1146/annurev.ecolsys.33.020602.095451

Deslauriers, A., Beaulieu, M., Balducci, L., Giovannelli, A., Gagnon, M. J., and Rossi, S. (2014). Impact of warming and drought on carbon balance related to wood formation in black spruce. Ann. Bot. 114, 335-345. doi: 10.1093/aob/ mcul11

Dietze, M. C., Sala, A., Carbone, M. S., Czimczik, C. I., Mantooth, J. A., Richardson, A. D., et al. (2014). Nonstructural carbon in woody plants. Annu. Rev. Plant Biol. 65, 667-687. doi: 10.1146/annurev-arplant-050213040054

Ebell, L. F. (1969). Variation in total soluble sugars of conifer tissues with method of analysis. Phytochemistry 8, 227-233. doi: 10.1016/S0031-9422(00) 85818-5

Farquhar, G. D., Ehleringer, J. R., and Hubick, K. T. (1989). Carbon isotope discrimination and photosynthesis. Annu. Rev. Plant Biol. 40, 503-537. doi: 10.1146/annurev.pp.40.060189.002443

Franks, P. J., and Beerling, D. J. (2009). Maximum leaf conductance driven by $\mathrm{CO} 2$ effects on stomatal size and density over geologic time. Proc. Natl. Acad. Sci. U.S.A. 106, 10343-10347. doi: 10.1073/pnas.090420 9106

Franks, P. J., Drake, P. L., and Beerling, D. J. (2009). Plasticity in maximum stomatal conductance constrained by negative correlation between stomatal size and density: an analysis using Eucalyptus globulus. Plant Cell Environ. 32, 1737-1748. doi: 10.1111/j.1365-3040.2009.02031.x

Franks, P. J., Doheny-Adams, T. W., Britton-Harper, Z. J., and Gray, J. E. (2015). Increasing water-use efficiency directly through genetic manipulation of stomatal density. New Phytol. 207, 188-195. doi: 10.1111/nph. 13347

Ghannoum, O., Phillips, N. G., Sears, M. A., Logan, B. A., Lewis, J. D., Conroy, J. P., et al. (2010). Photosynthetic responses of two eucalypts to industrialage changes in atmospheric CO2 and temperature. Plant Cell Environ. 33, 1671-1681. doi: 10.1111/j.1365-3040.2010.02172.x 
Gimeno, T. E., Camarero, J. J., Granda, E., Pías, B., and Valladares, F. (2012). Enhanced growth of Juniperus thurifera under a warmer climate is explained by a positive carbon gain under cold and drought. Tree Physiol. 32, 326-336. doi: 10.1093/treephys/tps011

Han, X., Tang, S., An, Y., Zheng, D. C., Xia, X. L., and Yin, W. L. (2013). Overexpression of the poplar NF-YB7 transcription factor confers drought tolerance and improves water-use efficiency in Arabidopsis. J. Exp. Bot. 64, 4589-4601. doi: 10.1093/jxb/ert262

Hikosaka, K., Onoda, Y., Kinugasa, T., Nagashima, H., Anten, N. P., and Hirose, T. (2005). "Plant responses to elevated CO2 concentration at different scales: leaf, whole plant, canopy, and population," in Forest Ecosystems and Environments, eds T. Kohyama, J. Canadell, D. S. Ojima, and L. F. Pitelka (Tokyo: Springer), 3-13.

Hou, Y., Qu, J., Luo, Z., Zhang, C., and Wang, K. (2011). Morphological mechanism of growth response in treeline species Minjiang fir to elevated CO2 and temperature. Silva Fenn. 45, 181-195. doi: 10.14214/ sf. 41

Huang, G., Rymer, P. D., Duan, H., Smith, R. A., and Tissue, D. T. (2015). Elevated temperature is more effective than elevated [CO2] in exposing genotypic variation in Telopea speciosissima growth plasticity: implications for woody plant populations under climate change. Glob. Change Biol. 21, 3800-3813. doi: $10.1111 /$ gcb.12990

Jamieson, M. A., Schwartzberg, E. G., Raffa, K. F., Reich, P. B., and Lindroth, R. L. (2015). Experimental climate warming alters aspen and birch phytochemistry and performance traits for an outbreak insect herbivore. Glob. Change Biol. 21, 2698-2710. doi: 10.1111/gcb.12842

Jónsdóttir, I. S., Khitun, O., and Stenström, A. (2005). Biomass and nutrient responses of a clonal tundra sedge to climate warming. Can. J. Bot. 83, 16081621. doi: 10.1139/b05-129

Kasurinen, A., Koikkalainen, K., Anttonen, M. J., Possen, B., Oksanen, E., Rousi, M., et al. (2016). Root morphology, mycorrhizal roots and extramatrical mycelium growth in silver birch (Betula pendula Roth) genotypes exposed to experimental warming and soil moisture manipulations. Plant Soil 407, 341-353. doi: 10.1007/s11104-016-2891-4

Lemoine, N. P., Doublet, D., Salminen, J.-P., Burkepile, D. E., and Parker, J. D. (2017). Responses of plant phenology, growth, defense, and reproduction to interactive effects of warming and insect herbivory. Ecology 98, 1817-1828. doi: 10.1002/ecy.1855

León-Sánchez, L., Nicolás, E., Nortes, P. A., Maestre, F. T., and Querejeta, J. I. (2016). Photosynthesis and growth reduction with warming are driven by nonstomatal limitations in a Mediterranean semi-arid shrub. Ecol. Evol. 6, 2725-2738. doi: 10.1002/ece3.2074

Li, Y., Liu, J., Zhou, G., Huang, W., and Duan, H. (2016a). Warming effects on photosynthesis of subtropical tree species: a translocation experiment along an altitudinal gradient. Sci. Rep. 6:24895. doi: 10.1038/ srep2 24895

Li, Y., Zhou, G., Huang, W., Liu, J., and Fang, X. (2016b). Potential effects of warming on soil respiration and carbon sequestration in a subtropical forest. Plant Soil 409, 247-257. doi: 10.1007/s11104-0162966-2

Lin, D., Xia, J., and Wan, S. (2010). Climate warming and biomass accumulation of terrestrial plants: a meta-analysis. New Phytol. 188, 187-198. doi: 10.1111/j. 1469-8137.2010.03347.x

Liu, D., Estiarte, M., Ogaya, R., Yang, X., and Peñuelas, J. (2017). Shift in community structure in an early-successional Mediterranean shrubland driven by long-term experimental warming and drought and natural extreme droughts. Glob. Change Biol. doi: 10.1111/gcb.13763 [Epub ahead of print].

McCulloh, K. A., Petitmermet, J., Stefanski, A., Rice, K. E., Rich, R. L., Montgomery, R. A., et al. (2016). Is it getting hot in here? Adjustment of hydraulic parameters in six boreal and temperate tree species after 5years of warming. Glob. Change Biol. 22, 4124-4133. doi: 10.1111/gcb. 13323

Michelot, A., Simard, S., Rathgeber, C., Dufrêne, E., and Damesin, C. (2012). Comparing the intra-annual wood formation of three European species (Fagus sylvatica, Quercus petraea and Pinus sylvestris) as related to leaf phenology and non-structural carbohydrate dynamics. Tree Physiol. 32, 1033-1045. doi: 10.1093/treephys/tps052
Mitchell, P. J., O’Grady, A. P., Tissue, D. T., White, D. A., Ottenschlaeger, M. L., and Pinkard, E. A. (2013). Drought response strategies define the relative contributions of hydraulic dysfunction and carbohydrate depletion during tree mortality. New Phytol. 197, 862-872. doi: 10.1111/nph. 12064

Moore, B. D., Cheng, S. H., Sims, D., and Seemann, J. R. (1999). The biochemical and molecular basis for photosynthetic acclimation to elevated atmospheric CO2. Plant Cell Environ. 22, 567-582. doi: 10.1046/j.1365-3040.1999. 00432.x

Pachauri, R. K., Allen, M., Barros, V., Broome, J., Cramer, W., Christ, R., et al. (2014). Climate Change 2014: Synthesis Report. Contribution of Working Groups I, II and III to the Fifth Assessment Report of the Intergovernmental Panel on Climate Change. Geneva: IPCC.

Poorter, H., Niinemets, Ü., Poorter, L., Wright, I. J., and Villar, R. (2009). Causes and consequences of variation in leaf mass per area (LMA): a meta-analysis. New Phytol. 182, 565-588. doi: 10.1111/j.1469-8137.2009. 02830.x

Pritchard, S. G., Peterson, C. M., Prior, S. A., and Rogers, H. H. (1997). Elevated atmospheric $\mathrm{CO} 2$ differentially affects needle chloroplast ultrastructure and phloem anatomy in Pinus palustris: interactions with soil resource availability. Plant Cell Environ. 20, 461-471. doi: 10.1046/j.1365-3040.1997. d01-92.x

Rasse, D. P., and Tocquin, P. (2006). Leaf carbohydrate controls over Arabidopsis growth and response to elevated CO2: an experimentally based model. New Phytol. 172, 500-513. doi: 10.1111/j.1469-8137.2006. 01848.x

Sala, O. E., Chapin, F. S. III, Armesto, J. J., Berlow, E., Bloomfield, J., Dirzo, R., et al. (2000). Global biodiversity scenarios for the year 2100. Science 287, 1770-1774. doi: 10.1126/science.287.5459.1770

Sendall, K. M., Reich, P. B., Zhao, C., Jihua, H., Wei, X., Stefanski, A., et al. (2014). Acclimation of photosynthetic temperature optima of temperate and boreal tree species in response to experimental forest warming. Glob. Change Biol. 21, 1342-1357. doi: 10.1111/gcb.12781

Sharwood, R. E., Crous, K. Y., Whitney, S. M., Ellsworth, D. S., and Ghannoum, O. (2017). Linking photosynthesis and leaf $\mathrm{N}$ allocation under future elevated CO2 and climate warming in Eucalyptus globulus. J. Exp. Bot. 68, 1157-1167. doi: $10.1093 /$ jxb/erw484

Smith, A. M., and Stitt, M. (2007). Coordination of carbon supply and plant growth. Plant Cell Environ. 30, 1126-1149. doi: 10.1111/j.1365-3040.2007.01708.x

Smith, N. G., and Dukes, J. S. (2013). Plant respiration and photosynthesis in global-scale models: incorporating acclimation to temperature and CO2. Glob. Change Biol. 19, 45-63. doi: 10.1111/j.1365-2486.2012.02797.x

Tang, X., Wang, Y. P., Zhou, G., Zhang, D., Liu, S., Zhang, Q., et al. (2011). Different patterns of ecosystem carbon accumulation between a young and an old-growth subtropical forest in Southern China. Plant Ecol. 212, 1385-1395. doi: 10.1007/s11258-011-9914-2

Wang, J., Duan, B., and Zhang, Y. (2012). Effects of experimental warming on growth, biomass allocation, and needle chemistry of Abies faxoniana in evenaged monospecific stands. Plant Ecol. 213, 47-55. doi: 10.1007/s11258-0110005-1

Wang, P., Heijmans, M. M. P. D., Mommer, L., van Ruijven, J., Maximov, T. C., and Berendse, F. (2016). Belowground plant biomass allocation in tundra ecosystems and its relationship with temperature. Environ. Res. Lett. 11, 055003. doi: 10.1088/1748-9326/11/5/055003

Wang, Y., Pederson, N., Ellison, A. M., Buckley, H. L., Case, B. S., Liang, E., et al. (2016). Increased stem density and competition may diminish the positive effects of warming at alpine treeline. Ecology 97, 1668-1679. doi: 10.1890/151264.1

Way, D. A., and Oren, R. (2010). Differential responses to changes in growth temperature between trees from different functional groups and biomes: a review and synthesis of data. Tree Physiol. 30, 669-688. doi: 10.1093/treephys/ tpq015

Zhang, L., Niu, H., Wang, S., Li, Y., and Zhao, X. (2010). Effects of temperature increase and grazing on stomatal density and length of four alpine Kobresia meadow species, Qinghai-Tibetan Plateau. Acta Ecol. Sin. 30, 6961-6969.

Zheng, Y., Xu, M., Shen, R., and Qiu, S. (2013). Effects of artificial warming on the structural, physiological, and biochemical changes of maize (Zea mays L.) leaves 
in northern China. Acta Physiol. Plant. 35, 2891-2904. doi: 10.1007/s11738013-1320-z

Zhou, G., Houlton, B. Z., Wang, W., Huang, W., Xiao, Y., Zhang, Q., et al. (2014). Substantial reorganization of China's tropical and subtropical forests: based on the permanent plots. Glob. Change Biol. 20, 240-250. doi: 10.1111/gcb. 12385

Zhou, G., Peng, C., Li, Y., Liu, S., Zhang, Q., Tang, X., et al. (2013). A climate change-induced threat to the ecological resilience of a subtropical monsoon evergreen broad-leaved forest in Southern China. Glob. Change Biol. 19, 1197-1210. doi: $10.1111 /$ gcb.12128
Conflict of Interest Statement: The authors declare that the research was conducted in the absence of any commercial or financial relationships that could be construed as a potential conflict of interest.

Copyright (c) $2017 \mathrm{Li}$, Zhou and Liu. This is an open-access article distributed under the terms of the Creative Commons Attribution License (CC BY). The use, distribution or reproduction in other forums is permitted, provided the original author(s) or licensor are credited and that the original publication in this journal is cited, in accordance with accepted academic practice. No use, distribution or reproduction is permitted which does not comply with these terms. 